\section{THE SURGICAL AID SOCIETY AND ITS METHODS.}

To the Editors of THE LANCET.

SIRs,-Most surgeons are under the impression that this body has for its object the providing of surgical apparatus to the poor, chiefly hospital patients, on the recommendation or certificate of a surgeon only as stated in their advertisements.

The following incident which has recently occurred and which I am led to believe is not an isolated case shows how grievously their confidence may be misplaced and requires an explanation from the society. A little child, under my care at the Children's Hospital, Shadwell, was recommended by me to get an apparatus and the requisite number of letters was collected. A lady interested in the child's welfare and who originally asked me to see her took her up to Salisbury-square and was there told by an elderly official that the doctor had ordered quite the wrong thing. She was advised to see another surgeon and sent away with a printed paper bearing the name of a surgeon to the National Orthopædic Hospital, Great Portland-street, with the cheering prospect of getting much more efficient treatment. Fortunately she refused to be cajoled by any such seductive offer and returned to me with the document. The first question I would ask is-Does the society or does it not provide apparatus as they state on the recommendation of any surgeon? If they do not then let the profession openly know that it is provided only subject to the approval of a specialist. What is absolutely indefensible is the flagrant attempt to divert patients from one surgeon to another, to say nothing of destroying the patient's confidence by the delicate suggestion of his incompetence. As this is a matter of great importance to hospital surgeons I trust you may find space for it in your valuable journal.

I am, Sirs, yours faithfully, Hy. Betham RoBinson.

Upper Wimpole-street, W., Feb. 13th, 1899

\section{MEDICAL AID ASSOCIATIONS.} To the Editors of THE LANCET.

SIRS, - Will you kindly allow me to ask your readers for copies of reports of medical aid associations?

$$
\text { I am, Sirs, yours faithfully, }
$$

32, Windsor-place, Cardiff, Feb. 7th, 2899 T. GARRETT HORDER.

\section{INSTRUCTION IN AN AESTHETICS. \\ To the Editors of THE LANCET.}

SIRS,-Is it not high time that the administration of anæsthetics was systematically taught in our medical schools? At present a medical man as soon as he is qualified is supposed to be able to administer anæsthetics, although he has probably never received systematic instruction in this subject. This is not fair either to the medical man or to the patient. I should like to offer the following suggestions: 1 . There should be attached to all hospitals in connexion with medical schools an honorary anæsthetist who should rank with the visiting staff and who should instruct the medical students, both practically and by lectures, in the administration of anæsthetics. 2. The General Medical Council should make this instruction compulsory. 3. No hospital should appoint as resident anyone who had not received such instruction.

Leeds, Feb. 7th, 1899.

I am, Sirs, yours faithfully,

Charles POWell White.

\section{THE DUTY OF THE PUBLIC VACCINATOR.}

\section{To the Editors of THE LANCET.}

SIRs,- The public vaccinator of the -_- district appears to be sending out notices to the parents of unvaccinated children irrespective of their position, stating that he intends to call on a certain date to "offer to vaccinate" their child. This is followed in due course by the visit and a tbreat that the visit will be repeated at intervals until the vaccination is permitted. At least, this was done to one of my patients, the vaccination of whose child was postponed by me on account of sickness. I consider the action of the public vaccinator, to say the least, ungentlemanly and presumptuous and I can assure him, firstly, that the child in question will not be vaccinated until I consider it in a proper state of bealth, and secondly, that when the child is vaccinated it will not be by the public vaccinator of

But what I desire to ask you, Sirs, is whether this procedure is sanctioned by the Local Government Board. I may add that the father of the child is in a lucrative business, has never had any children vaccinated at the expense of the ratepayers, and was greatly astonished at the public vaccinator's visit. I enclose the notice sent.

Feb. 12th, 1899.

I am, Sirs, your obedient servant,

L.R.C.P., M.R.C.S.

\section{THE NEW VACCINATION ACT: "COMFORT" FROM THE LOCAL GOVERNMENT BOARD.}

To the Editors of THE LANCET.

SIRS,-Early in December I asked my guardians to come to an agreement $r e$ the new vaccination fees. Their reply was a notification of a "resolution" (received on Dec. 31st) that they would pay the minimum fees. I then put it to the Local Government Board that the fault was not mine that no agreement had been arrived at and asked whether, if $I$ refused the guardians' fees, the guardians could summarily dismiss me. I also asked whether a mere "resolution" of the guardians constituted an "agreement" as required by Article 4 of the General Order. The Local Government Board replies are as follows (taking the last question first): "A resolution of the guardians does not constitute an 'arreement." " One would think from this that the Local Government Board would at once itself determine the fees to be paid in accordance with its own "General Order." But not so. I am informed that notwithstanding the neglect of the guardians to carry out the Order it is still within their power to terminate my contract should I fail to comply with their "resolution." The "comforting" part then comes : that in the event of the guardians dismissing me I shall be entitled to payment for work done up to the time of the expiration of my notice to quit.

When it is remembered that the vaccination officer cannot be dismissed by the guardians a feeling of surprise creeps over me.

Feb. 8th, 1899

I am, Sirs, yours faithfully,

$\mathrm{X}$.

\section{"THE EXPERIENCES OF A PUBLIC VACCINATOR." \\ To the Editors of THE LANCET.}

SIRS, - I am with many of my fellow public vaccinators quite able to confirm the statement of your correspondent as to the large amount of work and the small profit attendant on that work undertaken by him in his duties under this new Vaccination Act. But what he leaves unsaid is the loss of self-respect and mental degradation incurred in performing these duties. It is bad enough in the slums where one hears oneself announced as "a bloke as wants to vaccinate the babby" and a dirty slut, called the lady, comes down and declines one's offer in choice slang meant to be as offensive as can be produced; it is still worse at the villa where the maid leaves one on the steps while she puts the chain up and goes to consult her missus. After hearing interjections such as "The idea!" "What next!" the girl returns with "Please missus says she isn't at home; she doesn't intend to have it done at all, and it shall be done by her own doctor." In the cloud of one's mind caused by all these contradictions one finds oneself outside and to seek the interior of one's brougham to carry one to fresh insults. Two contiguous houses were of one mind not to open the door to me, and though I could feel the vibration of people moving about and my coachman could see the inmates through the glass above the door ascending and descending no response was made to my four visits on four separate weeks, and the only effect obtained was to produce merriment in the neighbours who looked and grinned at their windows. Cannot a new modus vivendi et operandi be agreed upon? Cannot the vaccination officer first obtain consent of these people and then carry the names of these consenting ones to the public vaccinator and so spare him so much fruitless toil, or cannot vaccination 